\title{
Impact of Foreign Aid on Foreign Direct Investment in South Asia and
}

\section{East Asia}

\author{
Rahim M. Quazi ${ }^{1}$, Michael F. Williams ${ }^{1}$, Rick Baldwin ${ }^{1}$, Jermaine Vesey ${ }^{1} \&$ Wayne E. Ballentine ${ }^{1}$ \\ ${ }^{1}$ College of Business, Prairie View A\&M University, Prairie View, TX 77446, USA \\ Correspondence: Rahim M. Quazi, College of Business, Prairie View A\&M University, Prairie View, TX 77446, \\ USA. Tel: 1-936-261-9225. E-mail: rmquazi@pvamu.edu
}

Received: September 23, 2014

Accepted: October 15, $2014 \quad$ Online Published: November 25, 2014

doi:10.5539/ibr.v7n12p44

URL: http://dx.doi.org/10.5539/ibr.v7n12p44

\begin{abstract}
This study analyzes the impact of foreign aid on foreign direct investment (FDI) inflows in selected countries in East Asia and South Asia - two regions that have received huge foreign aid as well as FDI inflows. Theoretically, foreign aid can either facilitate FDI by funding projects that raise the marginal productivity of capital, or crowd out FDI as the number of investment opportunities in developing countries is usually limited. Using the FGLS (Feasible Generalized Least Squares) panel estimation methodology with 1995-2012 panel data from 7 East Asian and 7 South Asian countries, this study finds that the impact of foreign aid on FDI is significantly positive and robust across several model specifications. The estimated results also suggest that FDI is significantly affected by corruption control, rate of return, infrastructure, human capital, market potential, and political stability, and East Asia enjoys a locational advantage in attracting FDI vis-à-vis South Asia. These results further our knowledge of the foreign aid-FDI dynamics in developing countries.
\end{abstract}

Keywords: foreign aid, foreign direct investment, East Asia, South Asia

\section{Introduction}

Foreign aid from developed countries and multilateral organizations (e.g. World Bank, IMF, etc.) has played an important role in the growth dynamics of developing countries in the post-WWII period. Many foreign assistance programs have been modeled after the U.S.-led Marshall Plan, which played a vital role in restoring economic stability in war-ravaged Europe, to assist the developing countries in their fight against poverty. Over the years, two competing views have emerged in the foreign aid literature about the efficacy of foreign aid programs. The traditional pro-aid view, which is based on the early theoretical development of the 1950's and 1960 's, holds that foreign aid complements the recipient economy's domestic resources, eases foreign exchange constraints, transfers modern know-how and managerial skills, and facilitates easy access to foreign markets -all of which contribute to positive economic growth (Chenery, 1965; Papanek, 1972). The radical anti-aid view, which grew out of empirical revelation that economic growth in some of the aid recipient countries has been less than satisfactory, argues that foreign aid supplants domestic resources, worsens domestic income inequality and trade balance, funds transfer of inappropriate technology, and in general helps sustain inefficient and corrupt governments in the recipient countries (Griffin \& Enos, 1970; \& Weisskopf, 1972).

Another type of foreign capital that can play a significant role in the growth dynamics of the recipient economies is foreign direct investment (FDI) - capital from private investors and multinational corporations. The development economics literature holds that FDI can fill at least three development gaps in recipient economies - i. "investment gap" by providing much needed capital for domestic investment, ii. "foreign exchange gap" by providing foreign currency through initial investment and subsequent export earnings, and iii. "tax revenue gap" by generating tax revenues through creation of additional economic activities (Smith, 1997). FDI can also help generate domestic investment in matching funds, facilitate transfer of managerial skills and technological knowledge, increase local market competition, create modern job opportunities, and increase global market access for locally produced export commodities.

An interesting strand of research has emerged that analyzes the relationship between these two types of foreign capital. The aid-FDI literature comprises two competing views - one view holds that foreign aid funded human capital building projects (e.g. schools, hospitals, etc.) and infrastructure projects (e.g. roads, highways, airports, electricity, telecommunications, etc.) raise the marginal productivity of capital, which can attract more FDI. The 
opposing view holds that since the number of investment opportunities in developing countries is usually low and many investment projects are financed by foreign aid, this actually crowds out other types of investment, including FDI. Only a few studies have analyzed whether foreign aid in fact facilitates or crowds out FDI in developing countries and the empirical evidence is inconclusive.

The purpose of this study is to analyze the relationship between foreign aid and FDI in selected countries in South Asia and East Asia - two developing regions that have received huge inflows of both types of foreign capital. The FGLS (Feasible Generalized Least Squares) panel estimation methodology is used on 1995-2012 panel data from 7 countries from East Asia -- Cambodia, China, Indonesia, Lao, Malaysia, Philippines and Vietnam, and 7 countries from South Asia -- Bangladesh, Bhutan, India, Maldives, Nepal, Pakistan, and Sri Lanka. The estimated results suggest that the impact of foreign aid on FDI is significantly positive and robust across several model specifications. This study also finds that FDI is significantly boosted by corruption control, higher rate of return, access to infrastructure, improved human capital, higher market size/potential, and political stability. The estimated results also suggest that East Asia enjoys a locational advantage in attracting FDI vis-à-vis South Asia.

The rest of the paper is organized as follows. Section 2 presents a review of the literature, section 3 describes the methodology, data and estimation, section 4 discusses results and policy implications and section 5 provides concluding remarks.

\section{Literature Review}

Among the early aid-FDI studies, Karakaplan et al. (2005) put forth the hypothesis that aid gives rise to increases in FDI, but only when the investment environment is conducive for investment. A good investment environment was defined as having good governance and financial market development. The hypothesis was empirically tested with a panel data analysis. The regression model controlled for openness, income level, and stability indexes. The estimated results provided robust support for the hypothesis, indicating that the mere presence of aid in a country is not enough to attract and maintain FDI. While this study provides insights into the relationship between aid and FDI, it is important to note that the study limited itself to the exploration of macro-level pull variables, but micro-level variables and push variables were not considered.

Blaise (2005) analyzed the impact of Japanese aid on promoting Japanese FDI in China. Blaise considered the use of macroeconomic frameworks a major limitation for similar aid-FDI studies, which is addressed in this study by using province level micro data. Using the conditional logit estimation method on 1980-1999 data, this study found that the effect of Japanese aid (as well as other factors, such as lower wages, human capital, proximity to Japan, etc.) on Japanese private investment location choice in China is significantly positive. The positive effect of aid is found to be marginally more important for the non-manufacturing sector vis-à-vis the manufacturing sector. This study concluded that utilization of foreign aid in developing infrastructure builds the foundation for attracting future FDI inflows.

Harms and Lutz (2006) analyzed whether there exists any relationship between aid and private foreign investment (sum total of FDI and foreign portfolio investment) in developing countries in the 1990s. This study used 1988-1999 data from 92 low-income and middle-income countries. Controlling for institutional and economic environment (i.e. government effectiveness, political instability, regulatory burden, economic development, trade openness, equity investment risk, etc.), this study found that the marginal effect of foreign aid on private foreign investment is almost zero. However, this effect is found to be positive in countries with weak regulatory institutions. These results are found to be robust across different samples and model specifications, and hold when foreign capital is disaggregated into FDI and foreign portfolio investment.

Asiedu et al. (2009) provides a solid theoretical and empirical analysis in establishing a relationship between foreign aid and FDI. This research involved the examination of aid-FDI data from 35 low income countries, including several South Asian and East Asian countries (e.g. Bangladesh, India, Pakistan, and Mongolia). The model for studying the aid-FDI relationship involved an analysis of risk, where risk was an independent variable, and FDI/GDP was the dependent variable. The model analyzed a country's likelihood to renege on contractual obligations, such as contract modifications or cancellations, expropriation of foreign owned assets, restriction on profit repatriation, and payment delays by governments. The estimated results suggest that although foreign aid may mitigate the adverse effect of risk on FDI, it cannot neutralize the negative effect of risk. This study does support the idea that foreign aid can facilitate foreign direct investment, but to what measurable degree is not certain.

Kimura and Todo (2010) used a gravity equation type model to analyze the "vanguard effect" - the effect of foreign aid from a particular donor country on FDI from the same donor country. The study found that in general 
the effect of aid on FDI is insignificant, and there is no positive infrastructure effect or negative rent-seeking effect of aid on FDI. However, the study also found a vanguard effect for Japanese aid, i.e. aid from Japan promotes FDI from Japan, which however does not facilitate FDI from other countries.

Similar to the Kimura and Todo (2010) study, Kang et al. (2011) provides a micro level analysis as to how foreign aid is related to FDI by two countries - Korea and Japan. As with the previous studies, this study did not reveal a strong relationship between foreign aid and FDI. This study used the gravity model and the GMM panel dynamic system estimation methodology on data from developing countries, including several South Asian and East Asian countries (e.g. Korea, China, Pakistan, Bangladesh, India, Sri Lanka, and Afghanistan). The estimated results suggest that only aid from Korea and Japan created more FDI inflow into their respective recipient countries.

Bhavan et al. (2011) explored the relationship between foreign aid and FDI for four South Asian countries (Bangladesh, Pakistan, India and Sri Lanka) over the 1995-2007 period. This study analyzed the macroeconomic environment of each country (i.e. savings, investment rates, inflation, trade policies, fiscal deficits, etc.) and found a mixture of long-run and short-run complementary relationships between FDI and both aid for physical capital and aid for human capital and infrastructure development. While the results varied slightly across the sample countries, the study found support for the hypothesis that foreign aid is positively related to FDI.

Selaya and Sunesen (2012) created a theoretical framework in which foreign aid affects a country's GDP by influencing the quantity of factors of production in the country. In their framework, foreign aid is split into two categories -- (i) funding for physical capital, and (ii) funding for "complementary factors" to physical capital (such as investments in education). In this framework, it is theoretically ambiguous whether foreign aid increases or decreases FDI, because there are two countervailing effects. The portion of foreign aid that funds physical capital should crowd out other sources of funding for physical capital, reducing FDI. On the other hand, the portion of foreign aid that funds complementary factors to physical capital should increase the marginal product of capital (such as a more educated worker making a manufacturing plant more productive), providing incentive for foreign investors to increase their funding of physical capital, increasing FDI. This study uses 1970-2001 panel data from 99 countries and finds that the overall effect of foreign aid on FDI is positive.

Donaubauer (2014) claims that some prior studies of the effects of foreign aid on FDI failed to adequately deal with several coefficient estimation problems, including endogeneity and serial correlation. He corrects for these problems with a Fully Modified OLS estimator employing a nonparametric correction. Using panel data from 63 countries from 1970-2012, this study finds that foreign aid slightly reduces FDI on average for the 63 countries, although almost half of the individual countries show a positive relationship between foreign aid and FDI.

\section{Model and Data}

The OLI paradigm developed by Dunning (1988) provides the basic theoretical framework of empirical FDI models. This paradigm is based on three factors - i. Ownership (O) factor addresses the availability of firm-specific resources and capabilities; ii. Location (L) factor addresses the search for new markets, efficiency, and strategic assets; and iii. Internalization (I) factor addresses transaction and coordination costs. In line with the current literature, this study formulates the following regression equation (subscript $i$ refers to countries and $t$ refers to time).

$$
\begin{gathered}
F D I_{i, t}=\alpha+\beta_{1} \text { Foreign Aid }_{i, t}+\beta_{2} \Delta F D I_{i, t-1}+\beta_{3} \text { Corruption Control }_{i, t}+\beta_{4} \text { Economic Freedom }_{i, t}+\beta_{5} \text { Rate of } \\
\text { Return }_{i, t}+\beta_{6} \text { Infrastructure }_{i, t}+\beta_{7} \text { Human }_{\text {Capital }}+\beta_{8} \text { Market Size }_{i, t}+ \\
\beta_{9} \text { Political Stability }_{i, t}+\beta_{10} \text { Region }_{i, t}+\varepsilon_{i, t}
\end{gathered}
$$

A second set of models is estimated where foreign aid is disaggregated into multilateral aid and bilateral aid. Selection of the explanatory variables included in equation (1) has been guided by the empirical literature. The lagged change in FDI $\left(\Delta \mathrm{FDI}_{\mathrm{i}, \mathrm{t}-1}\right)$ has been added following Noorbakhsh et al. (2001) and Quazi (2014); corruption has been added following Al-Sadig (2009), Ketkar et al. (2005), and Quazi (2014); economic freedom has been added following Quazi (2014); return on investment has been added following Edwards (1990), Jaspersen et al. (2000), and Quazi (2014); infrastructure has been added following Loree and Guisinger (1995) and Quazi (2014); human capital has been added following Hanson (1996), Noorbakhsh et al. (2001) and Quazi (2014); market size has been added following Jaspersen et al. (2000), Wei (2000) and Quazi (2014); and political stability has been added following Jaspersen et al. (2000) and Quazi (2014). These variables are explained next.

\subsection{Model Rationale}

Foreign Aid: The primary focus of this study is to estimate the impact of foreign aid on foreign direct investment. As discussed previously, foreign aid can, on one hand, facilitate FDI by funding projects that raise the marginal 
productivity of capital (by enhancing human capital and building up infrastructure), but, on the other hand, can also crowd out FDI since the number of investment opportunities in developing countries is usually scarce. This study uses foreign aid inflows to GDP ratio (AID/GDP) as a measure of aid. The a priori expected sign of $\beta_{1}$ is uncertain, as either sign is a plausible outcome.

Lagged Changes in FDI $\left(\Delta F D I_{t-1}\right)$ : Foreign investors are usually risk averse and tend to avoid unfamiliar countries. Therefore, it is important for countries aspiring to attract FDI to first establish a track record, which can help dispel the foreign investors' fear of investing in those countries. Furthermore, many multi-national corporations (MNCs) test new markets by staggering their investments, which gradually reach the desired levels after some time adjustments. This study uses net foreign direct investment inflows to GDP ratio (FDI/GDP) as a measure of FDI. The a priori expected sign of $\beta_{2}$ is positive, as incremental lagged changes in FDI $\left(\Delta F D I_{i, t-1}\right)$ should contribute positively toward the current level of FDI.

Corruption Control: Theoretically, corruption can lend either a grabbing hand by raising uncertainty and transaction costs, which should reduce FDI, or a helping hand by "greasing" the wheels of commerce in the presence of weak regulatory framework, which should facilitate FDI. This study uses the Corruption Perceptions Index (CPI) published by the Transparency International as a proxy measure of corruption control. The CPI index scores countries from 0 (highly corrupt) to 10 (very clean), so a higher CPI score reflects less corruption or more corruption control. Following the results obtained by Quazi (2014), which validated the grabbing hand hypothesis for South Asia and East Asia, the a priori expected sign of $\beta_{3}$ is positive (i.e. higher CPI score or more corruption control attracts more FDI).

Economic Freedom: The overall business environment should play a critical role in affecting a country's locational appeal to foreign investors. However, it is difficult to construct an accurate measure of the overall business environment, as it is shaped by a wide range of economic and non-economic factors. The Economic Freedom Index (EFI), jointly published by the Heritage Foundation and Wall Street Journal, has been used by many empirical studies as a proxy for overall business environment and investment climate. The EFI index includes, inter alia, measures of financial liberalization and trade openness - variables that have been used in many FDI studies as explanatory variables. To avoid multicollinearity, these variables are not included separately in the regression equation (1). The a priori expected sign of $\beta_{4}$ is positive, as enhanced economic freedom should attract more FDI.

Rate of Return on Investment: Higher rate of return on investment should motivate foreign investors to consider a host country more favorably. Most developing countries however lack well-developed capital markets, which makes it difficult to determine the rate of return on investment in those countries. To resolve this issue, several studies have used a reasonable proxy variable --the inverse of per capita income ${ }^{1}$. The rationale for this proxy variable is that return on investment should be positively correlated with marginal productivity of capital, which should be high in capital-scarce poor countries, where per capita income is low (or the inverse of per capita income is high). This study uses the natural log of the inverse of per capita real GDP (adjusted for purchasing power parity) as a proxy measure for rate of return on investment. The a priori expected sign of $\beta_{5}$ is positive, as higher rate of return on investment should attract more FDI.

Infrastructure: Availability of high-quality infrastructure (e.g. electricity supply, telecommunication networks, roads, highways, railways, airports, seaports, etc.) should increase productivity of resources in a country and boost its locational appeal to foreign investors. This study uses the natural log of per capita electricity use (in kilowatt hours) as a proxy for the availability of infrastructure ${ }^{2}$. The a priori expected sign of $\beta_{6}$ is positive, as availability of infrastructure should attract more FDI.

Human Capital: A higher level of human capital is a good indicator of the presence of skilled workers in a country. Availability of a skilled but cheap workforce can significantly enhance the locational advantage of a developing country for foreign investment. This study uses the natural log of life expectancy at birth as a proxy for human capital ${ }^{3}$. The a priori expected sign of $\beta_{7}$ is positive, as higher levels of human capital should attract more FDI.

Market Size: Some FDI is "market-seeking" in nature, i.e. the primary objective of MNCs undertaking foreign investment is to serve the host market. An important determinant of this type of FDI is the market demand of MNC product in host countries, which is generally strong in emerging countries, where growing numbers of urban consumers enjoy rising purchasing power. The sample countries included in this study comprise a number of emerging economies with booming urban population (e.g. China, Indonesia, Malaysia, Philippines, Vietnam, Bangladesh, India, and Pakistan). It is therefore possible that some FDI flowing to this sample has been attracted by the domestic market size/potential. This study uses the natural log of per capita real GDP as a proxy for the 
market size ${ }^{4}$. The a priori expected sign of $\beta_{8}$ is positive, as higher market size/potential should attract more FDI.

Political Stability: Political stability is a very important determinant of the locational appeal of a host country to foreign investors. Political instability usually creates an unfavorable business climate, which erodes the foreign investors' confidence in the host country and drives FDI as well as domestic capital away to safer havens. This study uses the "Political Stability and Absence of Violence" indicator developed by the Worldwide Governance Indicators (WGI) project as a proxy measure for political stability. The a priori expected sign of $\beta_{9}$ is positive, as higher levels of political stability should attract more FDI.

Region: It can be hypothesized that East Asia enjoys a locational advantage over South Asia as a destination of foreign direct investment due to several factors. The "China factor," high degree of government interventions, government-led export oriented industrialization, broad-based education policies, etc. may have created an overall economic orientation in East Asia that is more conducive to foreign investment vis-à-vis South Asia. Other factors that may have contributed to the locational advantage of the sample East Asian countries include proximity to capital-rich countries like Japan and Taiwan and prevalence of the Confucian culture, which may have created a more harmonious work environment there (Hofstede and Bond 1988). The dummy variable for regional difference takes the value of " 1 " for South Asia and "0" for East Asia. The a priori expected sign of $\beta_{10}$ is negative, as it is hypothesized that East Asia enjoys a locational advantage over South Asia as a FDI destination.

\subsection{Data Sources}

Data on annual FDI inflow, different types of aid (total aid, multilateral aid and bilateral aid), per capita real GDP, infrastructure, and human capital are collected from the World Development Indicators (World Bank 2014), economic freedom index is collected from the Index of Economic Freedom (Heritage Foundation/Wall Street Journal 2013), political stability index is collected from the Worldwide Governance Indicators (WGI 2013), and corruption index is collected from the Corruption Perceptions Index (Transparency International 2013). It should be noted here that due to missing data for several years for a few countries, the sample dataset is not fully balanced. However, given the large sample size used in estimation ( $n=125$ to 153), the estimated results are still robust. The estimates results and policy implications are discussed next.

\section{Results}

The regression equation (1) is estimated with the Feasible Generalized Least Squares (FGLS) panel methodology. Diagnostic tests (White test) revealed the presence of heteroscedasticity; therefore, the regression models are estimated with heteroscedastic panels. As the sample comprises short time series data for each country (note: the maximum number of observations for each country is only 18), it was assumed that the panels have a common autocorrelation parameter. A total of eight regression models are estimated, which are presented at the next page. Models 1-4 (Table 1) show the effects of foreign aid on FDI with four slightly different versions of equation (1), and Models 5-8 (Table 2) re-estimate these models by disaggregating foreign aid into multilateral aid and bilateral aid.

Model 1 shows that except for economic freedom, the other explanatory variables (i.e. incremental lagged changes in FDI, corruption control, rate of return, infrastructure, and regional difference) turned out generally statistically significant with the correct a priori signs, and the coefficient of foreign aid came out statistically significant and positive. In Model 2, 3 and 4, three other explanatory variables (human capital, political stability, and market size) are added separately to Model 1 . Each one of these variables came out statistically significant with the correct a priori signs, but they turned out insignificant when estimated jointly, which indicates the possible presence of multicollinearity among them. More importantly, the coefficient of foreign aid remained robust (statistically highly significant and positive) in all models. When foreign aid is disaggregated into multilateral aid and bilateral aid, the same pattern is found across all 4 models (Table 2: Models 5-8). The estimated results generally show strong robustness for the coefficients of all explanatory variables (except economic freedom) and particularly for the coefficients of different types of aid (total, multilateral and bilateral aid). 
Table 1. FGLS regressions (impact of foreign aid on foreign direct investment)

\begin{tabular}{|c|c|c|c|c|c|c|c|c|}
\hline \multirow{2}{*}{ Explanatory Variables } & \multicolumn{2}{|c|}{ Model 1} & \multicolumn{2}{|c|}{ Model 2} & \multicolumn{2}{|c|}{ Model 3} & \multicolumn{2}{|c|}{ Model 4} \\
\hline & Coeff. & z stat & Coeff. & z stat & Coeff. & z stat & Coeff. & z stat \\
\hline Intercept & -0.03 & -0.02 & -42.34 & -3.19 & -32.20 & -2.22 & -23.29 & -1.60 \\
\hline$\Delta \mathrm{FDI}_{\mathrm{t}-1}$ & 0.12 & 1.64 & 0.13 & $1.84^{*}$ & 0.12 & 1.53 & 0.13 & $1.70^{*}$ \\
\hline Aid & 0.47 & $4.35^{* *}$ & 0.31 & $3.20^{* *}$ & 0.23 & $2.15^{* *}$ & 0.35 & $3.14^{* *}$ \\
\hline Corruption Control & 0.24 & 1.60 & 0.22 & $1.82^{*}$ & 0.01 & 0.05 & 0.02 & 0.09 \\
\hline Economic Freedom & -0.03 & -1.53 & -0.02 & -0.80 & -0.01 & -0.42 & -0.01 & -0.29 \\
\hline Rate of Return & 0.99 & $2.74^{* *}$ & 1.35 & $3.96^{* *}$ & 0.91 & $2.48^{* *}$ & 2.03 & $2.87^{* *}$ \\
\hline Infrastructure & 1.77 & $5.18^{* *}$ & 1.34 & $3.84^{* *}$ & 0.86 & $2.37^{* *}$ & 0.73 & $2.10^{* *}$ \\
\hline Regional Difference & -0.61 & $-2.00^{* *}$ & -1.04 & $-3.18^{* *}$ & -1.04 & $-2.67^{* *}$ & -0.99 & $-2.66^{* *}$ \\
\hline Human Capital & & & 11.16 & $3.22^{* *}$ & 8.88 & $2.39^{* *}$ & 7.30 & $1.96^{* *}$ \\
\hline Political Stability & & & & & 0.58 & $2.40^{* *}$ & 0.67 & $2.62^{* *}$ \\
\hline \multirow[t]{2}{*}{ Market Size } & & & & & & & 1.09 & $1.94^{*}$ \\
\hline & \multicolumn{2}{|c|}{$\mathrm{n}=153$} & \multicolumn{2}{|c|}{$\mathrm{n}=153$} & \multicolumn{2}{|c|}{$\mathrm{n}=125$} & \multicolumn{2}{|c|}{$\mathrm{n}=125$} \\
\hline Diagnostic & \multicolumn{2}{|c|}{ Log likelihood = } & \multicolumn{2}{|c|}{ Log likelihood = } & \multicolumn{2}{|c|}{ Log likelihood = } & \multicolumn{2}{|c|}{ Log likelihood = } \\
\hline \multirow{3}{*}{ Statistics } & \multicolumn{2}{|c|}{-195.5} & \multicolumn{2}{|c|}{-184.9} & \multicolumn{2}{|c|}{-156.7} & \multicolumn{2}{|c|}{-161.7} \\
\hline & \multicolumn{2}{|c|}{ Wald $\chi_{7}^{2}=112.9$} & \multicolumn{2}{|c|}{ Wald $\chi_{8}^{2}=191.4$} & \multicolumn{2}{|c|}{ Wald $\chi_{9}^{2}=137.9$} & \multirow{2}{*}{\multicolumn{2}{|c|}{$\begin{array}{c}\text { Wald } \chi_{10}^{2}=124.4 \\
(\mathrm{P} \text { value }=0.00)\end{array}$}} \\
\hline & \multicolumn{2}{|c|}{$(\mathrm{P}$ value $=0.00)$} & \multicolumn{2}{|c|}{$(\mathrm{P}$ value $=0.00)$} & \multicolumn{2}{|c|}{$(\mathrm{P}$ value $=0.00)$} & & \\
\hline
\end{tabular}

**Coefficient statistically significant at $5 \%$; *Coefficient statistically significant at $10 \%$.

Table 2. FGLS regressions (impact of multilateral aid and bilateral aid on FDI)

\begin{tabular}{|c|c|c|c|c|c|c|c|c|}
\hline \multirow{2}{*}{ Explanatory Variables } & \multicolumn{2}{|c|}{ Model 5} & \multicolumn{2}{|c|}{ Model 6} & \multicolumn{2}{|c|}{ Model 7} & \multicolumn{2}{|c|}{ Model 8} \\
\hline & Coeff. & z stat & Coeff. & z stat & Coeff. & z stat & Coeff. & z stat \\
\hline Intercept & 0.25 & 0.12 & -44.03 & -3.21 & -30.98 & -2.17 & -22.30 & -1.55 \\
\hline$\Delta \mathrm{FDI}_{\mathrm{t}-1}$ & 0.13 & $1.65^{*}$ & 0.13 & $1.72^{*}$ & 0.13 & 1.60 & 0.14 & $1.82^{*}$ \\
\hline Multilateral Aid & 0.49 & $2.07^{* *}$ & 0.40 & $2.02^{* *}$ & 0.14 & 0.58 & 0.12 & 0.51 \\
\hline Bilateral Aid & 0.47 & $2.59^{* *}$ & 0.25 & 1.46 & 0.28 & 1.63 & 0.48 & $2.73^{* *}$ \\
\hline Corruption Control & 0.27 & $1.71^{*}$ & 0.24 & $1.90^{*}$ & -0.02 & -0.10 & -0.04 & -0.19 \\
\hline Economic Freedom & -0.04 & -1.55 & -0.01 & -0.71 & -0.01 & -0.41 & -0.01 & -0.21 \\
\hline Rate of Return & 1.04 & $2.89^{* *}$ & 1.32 & $3.93^{* *}$ & 0.90 & $2.48^{* *}$ & 2.06 & $2.89^{* *}$ \\
\hline Infrastructure & 1.78 & $5.17^{* *}$ & 1.27 & $3.49^{* *}$ & 0.90 & $2.46^{* *}$ & 0.81 & $2.29^{* *}$ \\
\hline Regional Difference & -0.63 & $-1.98^{* *}$ & -1.09 & $-3.20^{* *}$ & -0.97 & $-2.44^{* *}$ & -0.86 & $-2.23^{* *}$ \\
\hline Human Capital & & & 11.59 & $3.25^{* *}$ & 8.53 & $2.34^{* *}$ & 6.98 & $1.90^{*}$ \\
\hline Political Stability & & & & & 0.61 & $2.48^{* *}$ & 0.73 & $2.82^{* *}$ \\
\hline Market Size & & & & & & & 1.11 & $1.97^{* *}$ \\
\hline & \multicolumn{2}{|c|}{$\mathrm{n}=153$} & \multicolumn{2}{|c|}{$\mathrm{n}=153$} & \multicolumn{2}{|c|}{$\mathrm{n}=125$} & \multicolumn{2}{|c|}{$\mathrm{n}=125$} \\
\hline Diagnostic & \multicolumn{2}{|c|}{ Log likelihood = } & \multicolumn{2}{|c|}{ Log likelihood = } & \multicolumn{2}{|c|}{ Log likelihood = } & \multicolumn{2}{|c|}{ Log likelihood $=$} \\
\hline \multirow{3}{*}{ Statistics } & \multicolumn{2}{|c|}{-196.3} & \multicolumn{2}{|c|}{-186.3} & \multicolumn{2}{|c|}{-156.7} & \multicolumn{2}{|c|}{-161.2} \\
\hline & \multicolumn{2}{|c|}{ Wald $\chi_{8}^{2}=116.02$} & \multicolumn{2}{|c|}{ Wald $\chi_{9}^{2}=172.5$} & \multicolumn{2}{|c|}{ Wald $\chi_{10}^{2}=141.5$} & \multirow{2}{*}{\multicolumn{2}{|c|}{$\begin{array}{c}\text { Wald } \chi^{2}{ }_{11}=125.8 \\
(\mathrm{P} \text { value }=0.00)\end{array}$}} \\
\hline & \multicolumn{2}{|c|}{$(\mathrm{P}$ value $=0.00)$} & \multicolumn{2}{|c|}{$(\mathrm{P}$ value $=0.00)$} & \multicolumn{2}{|c|}{$(\mathrm{P}$ value $=0.00)$} & & \\
\hline
\end{tabular}

$* *$ Coefficient statistically significant at $5 \%$; Coefficient statistically significant at $10 \%$.

For the most part, the explanatory variables included in this study came out with satisfactory statistical results. Three variables (rate of return, infrastructure, and regional difference) turned out statistically significant with the correct a priori signs in all eight models; incremental lagged changes in FDI turned out statistically highly significant in five models and moderately significant in 3 models; corruption control turned out significant in 
three models; and three other variables - human capital, political stability and market size, turned out statistically significant in at least one model. Only one variable, economic freedom, turned out statistically insignificant in all models. This could be due to possible multicollinearity between the proxy variables of corruption control (CPI) and economic freedom (EFI), as the latter is a composite measure that includes "freedom from corruption" along with 10 other "freedom" variables. It is also possible that EFI inadequately captures the true effects of economic freedom on FDI, which can be addressed in future studies by exploring alternative proxy variables for economic freedom. The overall diagnostic statistics (measured by log likelihood and Wald $\chi^{2}$ statistics) came out satisfactory for all eight models.

The estimated results offer several policy implications. First, this study finds that foreign aid is a significantly positive determinant of FDI in South Asia and East Asia. This result lends credence to the hypothesis that foreign aid funded projects raise the marginal productivity of capital in the recipient countries, which helps attract more FDI to these countries. In order to boost their locational appeal to foreign investors, these countries should therefore ensure that foreign aid is allocated adequately and utilized properly in projects that enhance human capital (e.g. immunizations, schools, hospitals, etc.) and build up infrastructure (e.g. roads, airports, electricity, telecommunications, etc.).

This study finds that foreign investors' increased familiarity with a host country can attract more FDI to that country. This result suggests that once a country is able to successfully attract initial rounds of FDI that will in turn open the door to additional rounds of FDI, thus setting a virtuous cycle in motion. Countries aspiring to attract FDI should therefore utilize the available policy instruments, such as offering tax benefits to foreign investors, setting up special economic zones for foreign investment projects, etc., to motivate the foreign investors to invest in those countries for the first time, which is the key to attracting additional rounds of FDI.

Corruption control is found to significantly boost FDI. These countries should, therefore, focus on reducing corruption by enforcing the existing anti-corruption policies and/or adopting new strategies. Adopting anti-corruption measures may be politically difficult in the short run, but these measures will foster a healthy economic environment that is necessary for economic development in the long run. Greater market size/potential and higher return on investment are found to attract more FDI. Therefore, strategies should be adopted to promote higher economic growth and nurture an attractive investment climate, which per se is a desirable outcome. Political stability, human capital and infrastructure are also found to have positive impacts on FDI, which policymakers should take into account when formulating long-term strategies to enhance the locational appeal of their countries to foreign investors.

This study finds that, even after accounting for the economic fundamentals, East Asia enjoys a locational advantage vis-à-vis South Asia as a FDI destination. This regional difference may have been created by a number of factors, including that East Asia is home to several high-performing economies that have outperformed their South Asians counterparts in recent years; steady economic reforms have been successfully pursued under the strict supervision of authoritarian regimes in several East Asian countries; geographical proximity to Japan and Taiwan makes it easy for East Asian countries to receive FDI from these capital-rich countries; finally, prevalence of the Confucian culture, which emphasizes discipline, harmony, submission to hierarchy, and other unique cultural traits, may have also created a less confrontational business environment in East Asia that is conducive to foreign investment.

\section{Conclusions}

Development economists generally hold the view that two important sources of foreign capital (foreign aid and foreign direct investment) can play an important role in the growth dynamics of the recipient countries. An interesting strand of research analyzes the relationship between these two types of foreign capital. The aid-FDI literature holds that foreign aid can either facilitate FDI by funding projects that raise the marginal productivity of capital, or crowd out FDI as the number of investment opportunities in developing countries is usually limited. This study analyzes the impact of foreign aid on FDI inflows in East Asia and South Asia. Several regression equations are estimated with the FGLS (Feasible Generalized Least Squares) panel estimation methodology on 1995-2012 panel data from 7 East Asian and 7 South Asian countries.

Results estimated in this study suggest that foreign aid affects FDI inflows positively and this positive aid-FDI relationship is found to be robust across several model specifications. This study also finds that foreign investors' improved familiarity with the recipient economy, control of corruption, political stability, larger market size/potential, higher return on investment, improved infrastructure, and better human capital can boost FDI inflows. It is also found, in addition to the economic fundamentals, there still exists a regional difference in favor of East Asia over South Asia, which perhaps can be explained by a combination of geo-political, cultural and 
economic factors. While these results are generally consistent with the current FDI literature, however, finding foreign aid a robust and significantly positive determinant of FDI in South Asia and East Asia is a new contribution to the literature.

The principal policy recommendation from this study is that the aid-recipient countries should ensure that foreign aid is allocated adequately and utilized properly in projects that enhance human capital and build up infrastructure, which will help them boost their locational appeal to foreign investors. This study furthers our knowledge of the aid-FDI dynamics in South Asia and East Asia, which is important for formulating effective strategies to promote long-term economic development not only in these two regions, but also in developing countries in general.

\section{Acknowledgement}

This study is funded by a research grant from the College of Business, Prairie View A\&M University, Prairie View, Texas, USA.

\section{References}

Al-Sadig, A. (2009). The Effects of Corruption on FDI Inflows. Cato Journal, 29(2), 267-294.

Asiedu, E., Jin, Y., \& Nandwa, B. (2009). Does foreign aid mitigate the adverse effect of expropriation risk on foreign direct investment? Journal of International Economics, 78, 268-275. http://dx.doi.org/10.2139/ssrn.1352389

Beladi, H., \& Oladi, R. (2007). Does foreign aid impede foreign investment? In S. Lahiri (Ed.), Theory and Practice of Foreign Aid. Ch. 4, Elsevier.

Bhavan, T., Xu, C., \& Zhong, C. (2011). The relationship between foreign aid and FDI in South Asian economies. International Journal of Economic and Finance, 3, 143-149. http://dx.doi.org/10.5539/ijef.v3n2p143

Blaise, S. (2005). On the link between Japanese ODA and FDI in China: A micro-economic evaluation using Conditional Logit analysis. Applied Economics, 37, 51-55. http://dx.doi.org/10.1080/0003684042000281534

Chenery, H. B. (1965). Trade, Aid and Economic Development. In Robock and Soloman (Eds.), International Development. New York: Oceana Publications.

Donaubauer, J. (2014). Does foreign aid really attract foreign investors? New evidence from panel cointegration. Applied Economics Letters, 21(15), 1094-1098. http://dx.doi.org/10.1080/13504851.2014.909570

Dunning, J. (1988). The Eclectic Paradigm of International Production: A Restatement and Some Possible Extensions. Journal of International Business Studies, 19(1), 1-31. http://dx.doi.org/10.1057/palgrave.jibs.8490372

Edwards, S. (1990). Capital Flows, Foreign Direct Investment, and Debt-Equity Swaps in Developing Countries. NBER Working Paper no. 3497. http://dx.doi.org/10.3386/w3497

Griffin, K., \& Enos, J. (1970). Foreign Assistance: Objective and Consequences. Economic Development and Cultural Change, 18(3), 313-326. http://dx.doi.org/10.1086/450435

Hanson, J. (1996). Human Capital and Direct Investment in Poor Countries. Explorations in Economic History, 33, 86-106. http://dx.doi.org/10.1006/exeh.1996.0004

Harms, P., \& Lutz, M. (2006). Aid, governance and private foreign investment: Some puzzling findings for the 1990s. Economic Journal, 116, 773-90. http://dx.doi.org/10.1111/j.1468-0297.2006.01111.x

Heritage Foundation/Wall Street Journal. (2013). Index of Economic Freedom. Washington, DC: The Heritage Foundation.

Hofstede, G., \& Bond, M. H. (1988). The Confucius Connection: From Cultural Roots to Economic Growth. Organizational Dynamics, 16(4), 5-21. http://dx.doi.org/10.1016/0090-2616(88)90009-5

Jaspersen, F., Aylward, A., \& Knox, A. (2000). The Effects of Risk on Private Investment: Africa Compared with Other Developing Areas. In P. Collier and C. Pattillo (Eds.), Investment and Risk in Africa (pp. 71-95). New York: St. Martin's Press.

Kang, S. J., Lee, H., \& Park, B. (2011). Does Korea follow Japan in foreign aid? Relationships between aid and foreign investment. Japan and the World Economy, 23, 19-27. http://dx.doi.org/10.1016/j.japwor.2010.06.001 
Karakaplan, M., Neyapti, B., \& Sayek, S. (2005). Aid and foreign investment: International evidence. Departmental Working Paper, Bilkent University.

Ketkar, K., Murtuza, A., \& Ketkar, S. (2005). Impact of Corruption of Foreign Direct Investment and Tax Revenues. Journal of Public Budgeting Accounting and Financial Management, 17(3), 313-340.

Kimura, H., \& Todo, Y. (2010). Is foreign aid a vanguard of foreign direct investment? A gravity-equation approach. World Development, 38, 482-497. http://dx.doi.org/10.1016/j.worlddev.2009.10.005

Loree, D., \& Guisinger, S. (1995). Policy and Non-policy Determinants of US Equity Foreign Direct Investment. Journal of Business Studies, 26(2), 281-299. http://dx.doi.org/10.1057/palgrave.jibs.8490174

Noorbakhsh, F., Paloni, A., \& Youssef, A. (2001). Human Capital and FDI Inflows to Developing Countries: New Empirical Evidence. World Development, 29, 1593-1610. http://dx.doi.org/10.1016/s0305-750x(01)00054-7

Papanek, G. (1972). The Effect of Aid and Other Resource Transfers on Savings and Growth in Less Developed Countries. Economic Journal, 82, 934-950. http://dx.doi.org/10.2307/2230259

Quazi, R. (2014). Corruption and Foreign Direct Investment in East Asia and South Asia: An Econometric Study. International Journal of Economics and Financial Issues, 4, 231-242.

Selaya, P., \& Sunesen, E. (2012). Does Foreign Aid Increase Foreign Direct Investment? World Development, 40, 2155-2176. http://dx.doi.org/10.2139/ssrn.1129772

Smith, S. (1997). Restrictive Policy toward Multinationals: Argentina and Korea. Case Studies in Economic Development (2nd ed., pp. 178-189).

Transparency International. (2013). Corruption Perceptions Index. Retrieved on January 5, 2014, from http://www.transparency.org/policy_research/surveys_indices/cpi/2013

Wei, S. (2000). How Taxing Is Corruption on International Investors? Review of Economics and Statistics, 82, 1-11. http://dx.doi.org/10.1162/003465300558533

Weisskopf, T. (1972). The Impact of Foreign Capital Inflow on Domestic Savings in Underdeveloped Countries. Journal of International Economics, 2(1), 25-38. http://dx.doi.org/10.1016/0022-1996(72)90043-8

WGI. (2013). Worldwide Governance Indicators. Retrieved on January 5, 2014, from http://info.worldbank.org/governance/wgi/index.aspx\#home

World Bank. (2014). World Development Indicators. World Bank, Washington, DC.

\section{Notes}

Note 1. See Edwards (1990) and Jaspersen et al. (2000).

Note 2. Two other proxy variables for infrastructure (natural log of telephone lines per 100 people and natural $\log$ of road km per $100 \mathrm{sq}$. $\mathrm{km}$ of land area) were also included in alternative model specifications, but neither one turned out with satisfactory statistical properties.

Note 3. Two other proxy variables for human capital (natural log of per capita healthcare expenditures and share of GDP spent on healthcare expenditures) were also included in alternative model specifications, but neither one turned out with satisfactory statistical properties.

Note 4. At first glance, it may appear that there is perfect multicollinearity between the proxy variables used for market size (natural log of per capita real GDP) and rate of return on investment (natural log of the inverse of per capita real GDP, adjusted for purchasing power parity). However, it is not the case, as the former proxy variable uses per capita real GDP, while the latter proxy variable uses per capita real GDP adjusted for purchasing power parity; therefore, the two proxy variables are not perfectly multicollinear.

\section{Copyrights}

Copyright for this article is retained by the author(s), with first publication rights granted to the journal.

This is an open-access article distributed under the terms and conditions of the Creative Commons Attribution license (http://creativecommons.org/licenses/by/3.0/). 